\title{
A study on Audit Independence and Corporate Governance of Private Commercial Bankers of Bangladesh
}

\author{
Golam Mohiuddin \\ Institute of Education, Research and Training, University of Chittagong, Chittagong aangladesh \\ E-mail address: gmuddiniert@cu.ac.bd \\ Auditors lodge an exclusive position in the business commun when they nent an audit
}

\begin{abstract} for clients. Auditors are called upon to verify to financial statem nts to safeguc d the interest of various parties. In recent years the audit practice because of se ra hum empirical study shows that several factors effect on audit ind penaunce in Bà desh. The results show that there is a huge difference between auditors and bank $s$ on audit independence. It has come to the conclusion that for solving this problem well-establish corporate overnance can improve audit independence.
\end{abstract}

Keywords: Audit independence; auditor's perce corporate governance; economic dependence

\section{INTRODUCTION}

Separation of prop storship management and limited liability of members are the two major features of $\mathrm{a}$ ate bodic at require giving a single thought to the governance of these organization For an important advantage to investors and managers, not much of accountabilit was created them initially. Usually a company was seen as a selfregulatory bo $\mathrm{y}$ whis is a part of regulatory market mechanism, thus making it accountable primarily to th a et an to its members. Rapid growth in the size of the companies and the consequent con xities in their structures have, however, challenged this traditional perspectiv ll ove world; that is why corporate governance has become a topic of hot di sion hwell-developed as well as developing countries. The global movement for better corpo gorm. ice progressed by fits and starts from the 1980s. Corporate governance is the impleme tion of best corporate practices which enhance shareholders value in the long run at the same til c protecting the interests of other stakeholders. High-profile business failures such as Enron Corp., WorldCom, Inc., and Global Crossing, Ltd. have focused public's attention on how management manipulates earnings in an apparent attempt to deceive the unwary public. Public confidence in corporate governance structures and the ability of corporate boards to monitor and control management's behavior has been reduced to very low levels. Corporate governance deals with laws, practices and implicit rules that determine the company's ability to take informed managerial decisions vis-à-vis its claimants in particular, shareholders, creditors, customers, the state and employees. The present study on corporate governance is 
historical in nature. It seems that the concept has become widely circulated because of audit failure.

The basic objective of audit process is to ensure that the operations of an enterprise are carried out in good faith by the management without using the resources to satisfy self-interest. An auditor is expected to render his opinion on management's operations from the viewpoint of carrying out such functions in good faith. It is important to note that the focus of corporate governance, in its broadest interpretation, incorporates this objective of audit process itself. Then the question arises as to why we should focus on corporate governance now, when we can achieve the objective of the verification of management working in good faith. The rom is that audit has itself failed in the realization of the stated objective of verifying th opera $s$ carried out by the management. One of the major reasons for the failure of aud affectiven is the absence of auditor independence and this factor alone paved the vay corpor governance. In recent years the failure of auditor independence has nece oitated for udy on corporate governance in Bangladesh, as a sequel to the global phenom on.

The need for the study arises because (i) audit effectiveness bo fà aving $t$ way for corporate governance; and (ii) the crucial issue of auditor ndepend ha not been empirically tested in Bangladesh. With the background of thi p $\mathrm{pem}$, the p cht study aims at empirically testing the factors that hinder audit indene dence d also the factors that enhance auditor independence. This study has an argy acrut that ther $\%$ strong relationship between corporate governance and audit independen

\section{LITERATURE REVIEW}

Watts and Zimmerman (1983) have arge d th ars have incentives to maintain their independence, even in the absence of governm ital regulations, so that self-monitoring might be sufficient. At least since the secu es Act independence has been the focus of almost constant controversy, debate an dvsis. Tbere is widespread agreement by regulators, accounting practitioners, a va aumancs that auditor independence enhances auditor credibility.

It is argued th in endence $y$ nances the credibility of financial statement on two grounds. First, ind no dent tors increase the likelihood that financial statements conform to generally aco pted accountin cinciples (GAAP). Second, investors are more likely to rely on the finan state nnts if the auditor is independent. Under this set of arguments, auditor independence a cent role in enhancing the credibility of financial statements, and any threat the ditor in ence has undesirable effects on capital markets

(SEC 2000). $\mathrm{h}$ cring to more recent work that has been done on corporate governance, Snlu ar de corporate governance by stating that it 'deals with the ways in wh suppliers of finance to corporations assure themselves of getting a return on their investme, Taking a broad perspective on the issues, Gillan and Starks (1998) define corporate as the syst $m$ of laws, rules, and factors that control operations at a company. Irrespective of the particular definition used, researchers often view corporate mechanisms as falling into one of two groups: those internal to firms and those external to firms.

Of course, firms are more than just boards, managers, shareholders, and debt holders. As demonstrated by Pass (2004, pp. 52), corporate governance actually deals with the "duties and responsibilities of a company's board of directors in managing the company and their relationships with the shareholders of the company and the stakeholder groups". To put it into effective work, in essence, such dealing should be appropriately governed, regulated, imposed 
and enforced. Hart (1995) suggests "corporate governance issues arise in an organization whenever two conditions are present.

First, there is an agency problem, or conflict of interest, involving members of the organization - these might be owners, managers, workers or consumers. Second, transaction costs are such that this agency problem cannot be dealt with through a contract". Garvey and Swan (1994) assert that "governance determines how the firm's top decision makers (executives) actually administer contracts", while they also argue that governance arises when such contracts are incomplete. In accordance to the above, John and Senbet (1998) define corporate governance in a more comprehensive way since they argue that it dealc with mechanisms by which stakeholders of a corporation exercise control over corp cate ins rs and management such that their interests are protected'. It is worth noting $t^{1}$ by the te stakeholders we mean not just shareholders, but also debt holders as we $e^{11}$ as -financ stakeholders such as employees, suppliers, customers, and other intereste parties.

\section{OBJECTIVES OF THE STUDY}

The main objective of the study is to evaluate the dit in endence and corporate follows:

(1) to know the auditor's perceptions on the ecc

(2) to know the professional ethics of auditors an ankers and

(3) to know the auditor's and banker's momic depunchee.

\section{SCOPE OF THE STUDY}

There are 24 commercal
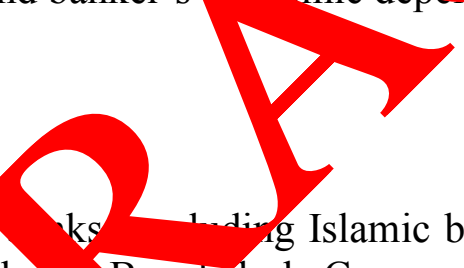

follows: (1) AB Bank I mited; Bangladesh Commerce Bank Limited; (3) Bank Asia Limited; (4) BRAC B a imited; (3) Kaka Bank Limited; (6) Dutch Bangla Bank Limited; (7) Eastern Bank Lir fed; Girst Security Bank Limited; (9) IFIC Bank Limited; (10) Jamuna Bank Limited; (1, Mercantl ank Limited; (12) Mutual Trust Bank Limited; (13) National Bank Limited (14) ational Cy, dit and Commerce Bank Ltd.; (15) One Bank Limited; (16) Premier Ban mit a; 17 Prime Bank Ltd.; (18) Pubali Bank Limited; (19) South East Bank Limited; (20) S Jard B rk Limited; (21) The City Bank Limited.; (22) The Trust Bank Limit u, Unı Commercial Bank Limited; and (24) Uttara Bank Limited. The study co ten rivate co nmercial banks of Bangladesh namely AB Bank Limited, BRAC Bank Lim. ank Limited, Dutch Bangla Bank Limited, Eastern Bank Limited, IFIC Bank Limited, reantile Bank Limited, National Bank Limited, Prime Bank Ltd., and Pubali Bank Limited. I main basis of the selection of the sample was the easy access and availability of the requisite data and information.

\section{LIMITATIONS OF THE STUDY}

This study has some limitations. One of its limitations is that due to unavailability of data it did not include all the bankers of all commercial banks working in Bangladesh. This study also does not cover the foreign commercial bankers due to non-availability of relevant data. 


\section{AUDIT INDEPENDENCE}

The concept of auditor independence has been argued from many perspectives. Many research works have been conducted on the auditor independence. From amongst them some of the important definitions and views have been presented in the study. The auditor independence has been defined by International Auditing Practices Committee of the International Federation of Accountants in its I.A.G.-3, Sept 1980 as the auditor should be straight forward, honest and sincere in his approach to his professional work. He must be fair and must not allow prejudice or bias to override his objectivity. He should maintain an immartial attitude and both be and appear to be free of any interest which might be regarded whater ts actual effect, as being incompatible with integrity and objectivity. Moizier (190 viewed in economic sense, the term auditor independence. There is an expectation the the ditor $\mathrm{w}$ have performed an audit that will have reduced the chances of a success $f_{1}$ negligen aw dit to a level acceptable to the auditor. In the language of economics $t^{\prime}$ audit will form auditor work until the cost of undertaking more work is equal to the nen audi derives in terms of the reduction in the risk of a successful lawsuit being oossible. the represents the minimum amount of work that the reader can expect the u $r$ to perfo However, all auditors are individuals with different attitudes to risk and $r e$ rn an one auditor's minimum standard of audit work will not necessarily be that of a virugue.

\section{1. Origin of audit independence}

Independent auditing is an essential feature of ficient o apital markets. The auditing profession in the developed world has long a red that thective of independent audits is to render an expert opinion on the fair soncial statements. Independence both historically and philosophically, is the foundat on thy ublic accounting profession and upon its maintenance depend the profen's stre gth and its stature. The concept of auditor independence has varied over th last 0 years $y=$ a general sense, auditor independence has borne a relationship to the preva $\mathrm{g}$, mercian environment in different time periods. There has not, however, been a g camran on from one concept of auditor independence to another. The initial concept of tor indep ace, which arose during the nineteenth century, was based on the premi , p rily Britsh in origin, that the principal duty of professional accountants and tors was oyersight of absentee investments in the existing and former colonies of the Briti conceive of ditor as a lvocates for audited entities. British investors explicitly forbade auditors from $\mathrm{h}$ ting on vorking in the businesses that they audited. At the same time, as long itors in the the primary loyalty to the investors back home, the scope of pro ssion account ig services could be reasonably broad. This initial concept of auditor inde sed during the late nineteenth and early twentieth century. During this time there on economic shift from capital coming primarily from foreign sources to capital deriving $\mathrm{p}$ arily from domestic sources. The crux of the management-auditor relationship is often viewed in terms of the independence and objectivity of the auditors. However, in order to form an independence and objective view of something the auditors need to be aware of it.

\subsection{Importance of audit independence}

The audit of accounts in the corporate sector by an independent auditor is obligatory by statute which defines his duties rights and powers, It is essential because of the separation of ownership from the management in the corporate sector as the former needs someone who can keep a professional watch on the latter and to whom they can trust for the reliability of accounts 
as the preparation of financial statement is the prerogative of the management. The auditor has not much to suggest on the form and adequacy of financial statement and independent auditor is responsible for his audit report. The reliability of an audit report is nothing but the degree of trust reposed by its users. The various users are bound to react differently because of the variation in their nature and objectives. The following are some of the important features of auditor independence:

(1) The reliability of auditor's independence depends on auditor's independence on the one hand, and the degree of his experience, competence and knowledge, on the other;

(2) The independence of the auditor is of prime importance as his report is pers subjective in nature;

(3) Independence is a state of mind and implies that auditors should remain enough withstand any type of influence;

(4) Independence is of prime importance as wide spectrums of user are teres in his professional report and if his independence is not maintained cont ons ors will be belied;

(5) The auditor is beholden to be independent without re ting to co rather than enlighten the business community by his work and re ort o he task en, usted to him in a clear straight forward manner; and

(6) Traditional view of auditor independence is thr lack of indepe ence will reduce the importance placed on audit reports and tha investment and loan decisions will be impaired.

\section{3. Empirical evidences regarding audit dependen}

Auditor independence is an issue that $h$ be . The global conception among users of accoun $s$, and nas always been-quite rightly threat. If one wants to place trust in the audior port, it ust be a precondition that the views expressed by the auditor are based on ectiv y. Objec sity can only be achieved if the auditor is independent of the client. uas been a significant issue in accounting literature in recent years

This is often tes a tatistical aysis of the relationship between audit fees, non-audit fees, qualified audit ports There is a broad range of accounting literature that investigates whether the inde pendence of th ditor has been actually impaired. Majority of the perceived independence esear has emarated from the developed countries, especially in the United States, where re have ten two government commissions, viz., The Cohen Commission (1978) and the adw $y$ Commission (1987) with many debates about the effect of man gem adviso ervices on the independence of the auditors. However, the views of n2. sha eholders rave not been sought in much of this research.

uIt (1, 5) specifically focused on Non-Audit Services (NASs). Third parties were asked w her management consulting seriously impaired CA's audit independence. There were great ariations in views. It was found that 43 percent did not think so (indeed 20 percent indicated that their confidence in audit reports were thereby improved), 33 percent did think so and remaining 24 percent were unsure. Titard (1971) undertook a similar study, asking financial statement users on whether NAS's provision to audit clients may result in CA's losing some of their audit independence. The interesting feature of this study was that this same question was asked with respect to 33 specific types of services. Over 20 percent of respondents answered in the affirmative to five types of service: mergers and acquisitions (32 percent), executive recruitment (27 percent), policy determination ( 27 percent), personal appraisal and/or selection (23 percent), and executive and wage incentive plans ( 21 percent). It was noticeable that no 
single item was checked by more than one-third of respondents, although 49 percent answered "Yes" to an initial question asking about NAS generically. Respondents were asked also whether each service should be prohibited assuming separation of personnel. For the above five services, the percentage agreeing was between 10 percent and 20 percent. Emby and Davidson (1997) conducted an experiment using auditors to examine the impact of four factors (including NAS provision) on auditor's ability resist management pressure in a dispute over the disclosure of a contingent claim.

They found that auditors were more likely to insist on disclosure when they provided the client with NAS. Hussey (1999) asked the UK finance directors about a range of issues concerning the familiarity threat and auditor independence. One question as ed wh or auditors should be allowed to undertake other than audit work for the same clie The major agreed that joint provision should be allowed, however 20 percent of judep ant pub respondents disagreed, compared to 13 percent of private company resp ndents. $K$ ish nd Levine (2000), a survey commissioned by the ISB indicated that resp tents tieved at the evolution of audit firms into consulting fields was logical and pr vis 1 most nsulting services was not likely to create real problem of independence It is be at thad audor's responsibility and independence are crucial issues underlying 10 ependent ating function and has significant implications on the development of audi $\mathrm{g}$ sta $\mathrm{ds}$ and practices. In this regard, a survey was taken up by Lin (2004) in China w opect to a obligation to detect and reporting frauds and thir party liability or auditors. The study evidenced the emergence of the expectation ga in China nd the majority of audit independence by reducing governmental control o terventio and moving towards selfregulation of the profession. This study has limitation onse that it should cast light on understanding of the institutional setting an ted development of independent audits in China and may also serve as an annotation o tro accounting reform debates in the western world. Myers (2005) peranived tha audit independence is fundamental to the profession credibility. The audi ina endence can be viewed from two angles: (i) Actual independence is the achieve to actual freedom from bias, personal interest, prior commitment to an interest sus romy undue influence or pressure; and (ii) perceived independence is the beli financic nort users that actual independence has been achieved.

\section{CORPORATAGOVERN GE}

Despre the term corporate governance is relatively new; the aspects surrounding it have been aroun ince th first half of the century (Berle and Means 1932; Smith, 1776). In the o ode ociety very first corporate governance codes were established in the USA in th $70 \mathrm{~s}$, neriod iy which the corporate sector of the country was confronted with a wave of mergo III mone takeovers. In 1978, a report was published by the so-called Business Roundta entitled "The role and composition of the board of directors of the large publicly owned corp sration" as a response to a trend of increased corporate criminal behaviour, as well as to support the establishment of new laws to set clear boundaries to hostile takeovers (Aguilera and Cuervo-Cazzura, 2004). In Europe, the first code was established in 1992 with the issuing of the so-called "Cadbury Report". This report was published after increased public concern about a series of unexpected failures of major British companies such as Polly Peck, P\&C, BCCI and Maxwell (Parkinson, 1993). The Cadbury Report in1992, containing a code of best practices for listed companies, added an additional source of regulation to the British corporate governance environment in parallel with the relevant legislation. 
The widely accepted positive outcomes of that initiative have instigated the adoption of similar codes of best practice in almost all European Union countries. Yet, the appreciation for codes as an instrument to improve corporate governance systems increased only after 1997. Between 1992 and 1997 only three countries (Spain, The Netherlands and France) established a code. From 1998 several other European countries decided to come up with their own version of a corporate governance code. By 2004, a total of 22 European countries has established their own code, and in some cases even more than one. Reviewing the various definitions of corporate governance it is clear that they all refer to the existence of conflicts of interest between insiders and outsiders arising from the separation of ownership and control. During therecent past a growing interest in corporate governance has been observed. In the fir $a$ plac efficiency of the prevailing governance mechanisms has been questioned while is debate intensified following financial scandals and business failures and, more recntly, umber high visibility accounting frauds allegedly perpetrated by managers (En on, World $)$. The definition of corporate differs depending on one's view of the world. Tny ex ing st res in good corporate governance have focused on: the roles of non-ect versus xecutive members of the board (Pass, 2004), the independence of the boar of directo Zans stra, 2002), the role, independence and disclosure of audit committee (Re7 a al., 2003), enforcement of compliance and role of internal auditors (Vinten, 1998 000, 2). They are altogether grouped into under mentioned values of corporate gove name perspe

* Accountability (Spira, 2001);

* Integrity (Grant, 2003);

* Efficiency (Walker and Fox, 2002); and

* Transparency (Rezaee et al., 2003).

To explain the primary impediments to goo ance, the International Swaps and Derivatives Association (ISDA) (2002) ren ads us that modern economic theory has established an approach to const uct corpor te governance through the separation of two main functions in firms, which

1) Principals: The ow cro of $\mathrm{t}$ companes who hold claims over the net income of the company's busin no matter ather it is positive or negative, who then appoint the agent; and

2) Agents: Ag are tho vo execute duties and responsibilities in the companies on behalf $g$ the $\mathrm{p}$ incipals.

This sep ti is ho ever, linked and governed through proper "agency relationship" at various lavels, a otb crs "between shareholders and boards of directors, between boards and enion anagen , between senior and subordinate levels of management" (ISDA, 2002, pr. In ach a prizcipal-agent relationship, there is always "inherent potential for conflicts within rmucumse the economic incentives faced by the agents are often different from those faced by principals" (ISDA, 2002, p. 5). According to ISDA (2002), all companies are exposed to gency problems, and to some extent develop action plans to deal with them. These include establishing such measures as: "controls on the actions of agents, monitoring the actions of agents, financial incentives to encourage agents to act in the interest of the principals, and separation of risk taking functions from control functions" (ISDA, 2002, pp. 5). It is safe to say that, corporate governance covers all aspects of firms; therefore the existence of good corporate governance wills great effect firms. Furthermore, now a day's firms should think in interdisciplinary way; it means they have to accept new conditions. According to Wilson (2000), new rules of corporate conduct could be considered as follows: 
a) Legitimacy: To earn and retain social legitimacy, the corporation must define its basic mission in terms of the social purpose it is designed to serve rather than as the maximization of profit;

b) Governance: The Corporation must be thought of, managed, and governed more as a community of stakeholders and less as the property of investors;

c) Equity: The corporation must strive to achieve greater perceived fairness in the distribution of economic wealth and in its treatment of all stakeholder interests;

d) Environment: The corporation must integrate the practices of restorative economics and sustainable development into the mainstream of its business strategy;

e) Employment: The Corporation must rewrite the social contract of work values of the new workforce and increase both the effectiveness and loyal employ and the corporation;

f) Public/private-sector relationships: To ensure the success of the poy er shift, co rati hs must work closely with governments to achieve a viable od pu icly a epted redefinition of the roles and responsibilities of the public and iv. ctors; a

g) Ethics: The Corporation must elevate and monitor the leve of ethica rfor ance in all its operations in order to build the trust that is the found af sound is conships with all stakeholder groups.

In accounting and auditing dimensions, the co porate governan may play vital role, because good corporate governance leads to more a lit independence, in other words there is a positive relationship between corporate governanc nd audit in dependence. One of the key elements of audit practice is independence as explain

\section{RESEARCH METHODOLOGY OF Th ESTOY}

This study gives emphas on he perc ations of auditors and bankers on auditor independence. It is usually her at enomic considerations basically influence the level of auditor independence lead is o o tivenus or effectiveness of audit process. The influence of economic considerat s on audi independence was considered through eight variables given in the ensuing ble. study $h, s$ focused on the perception of 120 private commercial bankers and $15 \mathrm{pr}$ soional tered accountants of Bangladesh. The questionnaire consisted of five variable o, which were h $\mathrm{A}$ to decrease audit independence and four variables, which were held to reas adi independence in Bangladesh. All these variables were to be rated by the sample ondents 5 -point Likert scale having the ratings of "strongly disagree" (1) and "s+ (5) The statistical tools used in the study included mean value, median valy stan ard devi on, Mann-Whitney test and $\mathrm{Z}$ value for the purpose of analysis and intê.

\section{HYPO' AESES OF THE STUDY}

In carrying out the study, the following hypotheses were identified:

a) Audit independence is lower due to self-interest of the auditors;

b) The self-interest reducing the audit independence is perceived with higher weighted points by the bankers than the auditors; and

c) Auditors perceive lower actual values for economic consideration than the bankers. 


\section{FINDINGS AND ANALYSIS OF THE STUDY}

Table 1 highlights the results of respondents' perceptions comprising of auditors and bankers on economic and regulatory considerations affecting the independence of auditors and eight factors are included to study of these factors on auditor independence. It is interesting to note that both the auditors and bankers recognize that these factors influence auditor independence. Furthermore, according to the Mann-Whitney test there is a significant difference between two parties on all eight factors $(p<0.05)$. In the other words, there is a significant perception gaps in all factors between auditors and private commercial bankers in Bangladesh. The auditors perceived the independence level by assigning the man van ff 3.559 implying that these factors reduced independence of auditors. Howey the bank expected more from auditors in eight dimensions and they expected that the ill es ts of the factors affecting independence should be reduced and they assigned the rean value

Table 1. Factors effecting to independence

\begin{tabular}{|c|c|c|c|c|c|c|c|c|}
\hline \multirow{2}{*}{ Statements } & \multicolumn{3}{|c|}{ Auditors } & & & & \multicolumn{2}{|c|}{ Significance } \\
\hline & Mean & Median & & & edh & S/dev. & $\begin{array}{c}\text { Mann- } \\
\text { Whitney }\end{array}$ & $\mathrm{Z}$ \\
\hline $\begin{array}{l}\text { Economic dependence of the } \\
\text { auditor on the client }\end{array}$ & 3.168 & 3 & 1. & 3.789 & 4 & 0.945 & -8.415 & 0.000 \\
\hline Audit market competition & 3.609 & 4 & & 3.465 & 3 & 1.665 & -8.676 & 0.000 \\
\hline $\begin{array}{l}\text { Receiving payment from } \\
\text { non-audit services }\end{array}$ & 2.799 & & & & 4 & 0.945 & -7.578 & 0.000 \\
\hline $\begin{array}{l}\text { Receiving gifts and presentations } \\
\text { from management }\end{array}$ & & 3 & & 4.401 & 4 & 0.855 & -6.822 & 0.000 \\
\hline The regularity of frame work & & 4 & 0 & 3.402 & 3 & 1.125 & -8.505 & 0.000 \\
\hline The corporate go & & & 1.026 & 3.357 & 4 & 1.323 & -8.685 & 0.000 \\
\hline The great use of au & & 4 & 0.981 & 3.789 & 4 & 1.521 & -7.875 & 0.000 \\
\hline Professional e & & 4 & 0.810 & 3.447 & 3 & 0.801 & -9.395 & 0.000 \\
\hline & 3.5 & - & - & 3.708 & - & - & - & - \\
\hline
\end{tabular}

Further, th udito perceptions of the economic and considerations like client's econ mig rth, re gifts and presentations from management, in the executive function at leve rather the bankers, while the perceptions regarding audit market competition, the regul. ork, the corporate governance, the great use of audit committees and professic ethic guidance are higher than bankers'. It is interesting to note that the auditors believe the corporate governance effects on audit independence. In other words the wellcorporate governance increase audit independence. The auditors also believe audit market competition reduces audit independence and audit committees of private commercial banks and professional ethic guidance increase audit independence. However, private commercial bankers do not agree on these matters with auditors. The private commercial bankers believe the economic dependence of the auditor on the client, receiving payment from non-audit services, receiving gifts and presentations from management and receiving gifts and presentations from management do seriously affect audit independence and impair independence of Bangladeshi auditors. 


\section{CONCLUSIONS}

The new concept of auditor independence requires one that specifically incorporates the propositions that auditors should not be advocates for their clients, and management should not be able to influence the audit fee and the scope of the audit. Without a transition to this concept, auditor independence standards will most likely be primarily cosmetic and will not provide sufficient assurance that auditor is in fact independent from client management. The primary purpose of an independent audit is not the detection of fraudulent financial reporting, as long as the public's perceptions remain the way they are. The auditor's best protection againatampty pockets is to look for fraudulent financial reporting with each and every indep ndent it regardless of whether it will have a material effect on the statements. Audit opip on finano statements renders the level of truth and fairness in preparing and presenting financ statements and also of representational faithfulness of corporate gove nance. Th udit ors strongly believe that corporate governance in Bangladesh will incre aud ndepe ence, therefore, it is crucial to Bangladeshi finance sectors to well-esta ${ }^{1}$ ish ,orate $g$ yernance according to business requirements. In addition, the present stud reveals a ley 1 of auditor independence and this level indicates the pathetic situation $\mathrm{i} / \mathrm{neffective}$ dit process. If auditors eulogize audit as the sacred act of them, private on merc hankers and third parties condemn it as a perfunctory legal duty devoid of any ucu ility. Re rizing this failure of audit process, it has been embarked upon cleansing th corporate Bangladesh through the much hyped corporate governance, the effectiveness of $\mathrm{w}$, th is still unfler doubt needing proactive institutional framework in Bangladeshi private comn ial banke $\mathrm{s}$.

\section{References}

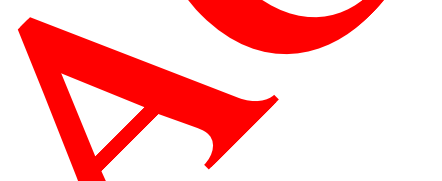

[1] Garvey, G. and P. Swa Tho conom s, of Corporate Governance: Beyond the Marshallian firm, Journ Cor orate Fizance 1 (1994) 139-74.

[2] Gillan, S. and St L. A Sun of Shareholder Activism: Motivation and Empirical Evidence, Con mpor Financ Digest 2(3) (1998) 10-34.

[3] Grant, The olution $\alpha$ Corporate Governance and its Impact on Modern Corporate A Tale mo crica, 1 yagement Decision 41(9) (2003) 923-34.

[4] Hart, . Corpo Governance, Some Theory and Applications, The Economic Journal $-689$.

[5] Huss , R. The Familiarity Threat and Auditor Independence, Corporate Governance 7(2) (1999) 190-197.

[6] International Swaps and Derivatives Association (ISDA). 17th Annual General Meeting, Berlin, April, (2002).

[7] John, K. and Senbet L. Corporate Governance and Board Effectiveness, Journal of Banking and Finance 22 (1998) 371-403. 
[8] Kornish, L., and Levine C.B. Discipline with Common Agency: The Case of Audit and Non-audit Services, SSRN, Working Paper (2000).

[9] Lin, J. Z., and Chen F. An Empirical Study of Audit 'Expectation Gap' in The People's Republic of China, International Journal of Auditing 8 (2004) 93-115.

[10] Moizier, P. Independence in Current Issues in Auditing, (eds.,) by M Sherer and S Turley, Paul Chapman publishing Ltd.(1991).

[11] Myers, P. J. Perceived Auditor Independence: The Neglected Vi of Natu Shareholders, (2005).

[12] Parkinson, J. Corporate Power and Responsibility: Issues in th 1 ry Com any Law, Oxford University Press, Oxford (1993).

[13] Pass, C. Corporate Governance and the Role of Non - xecu. Directors in Large UK Companies: An Empirical Study, Corporate Gove nume 4(2) (4) y52-63.

[14] Rezaee, Z., Olibe K. and Minmier G. Improvin Corporate g vernance: the Role of Audit Committee Disclosures, Managerial Auditing J al 18(6/7) (2003) 530-537.

[15] Schulte, T.A. Jr. Compatibility of Mana eme alting and Auditing, The Accounting Review (1965) 587-593.

[16] SEC. Final Rule: Revi of t commiosion's Auditor Independence Requirements, Release No. (2000)

[17] Securities and chan Commission (2000).

[18] Shleife A. and Vishny R. A Survey of Corporate Governance, Journal of Finance 52 (1997)

Smit A. Cam sell, R. and Skinner, A. (Eds.), An Enquiry into the Nature and Causes f Nations (1976 re-edition), Clarendon Press, Oxford (1776).

[20] Spira, L. Enterprise and Accountability: Striking a Balance, Management Decision 39(9) (2001) 739-48.

[21] Titard, P.L. Independence and MAS-Opinions of Financial Statements Users, Journal of Accountancy 1 (1971) 47-52.

[22] Treadway Commission. Fraudulent Financial Reporting, New York: American Institute of Certified Public Accountants (1987). 
[23] Vinten, G. Corporate Governance: An International State-of-the-Art, Managerial Auditing Journal 13(7) (1998) 419-31.

[24] Vinten, G. Corporate Governance: the Need to Know, Industrial and Commercial Training 32(5) (2000) 173-178.

[25] Vinten, G. The Corporate Governance lessons of Enron, Corporate Governance 2(4) (2002) 4-9.

[26] Walker, G. and Fox M. Corporate Governance Reform in East Asta Corporc Governance 2 (2002) 84-89.

[27] Watts, R., and Zimmerman J. Agency Problems, Auditing, tho eory o the Firm: Some Evidence, Journal of Law and Economics 26 (1983 13-33.

[28] Wilson, I. The New Rules: Ethics, Social Resw bility à Styategy, Strategy \& Leadership 28(3) (2000) 12-16.

[29] Zandstra, G. Enron, Board Governance and Mc Failings Corporate Governance 2(2) (2002) 16-19.

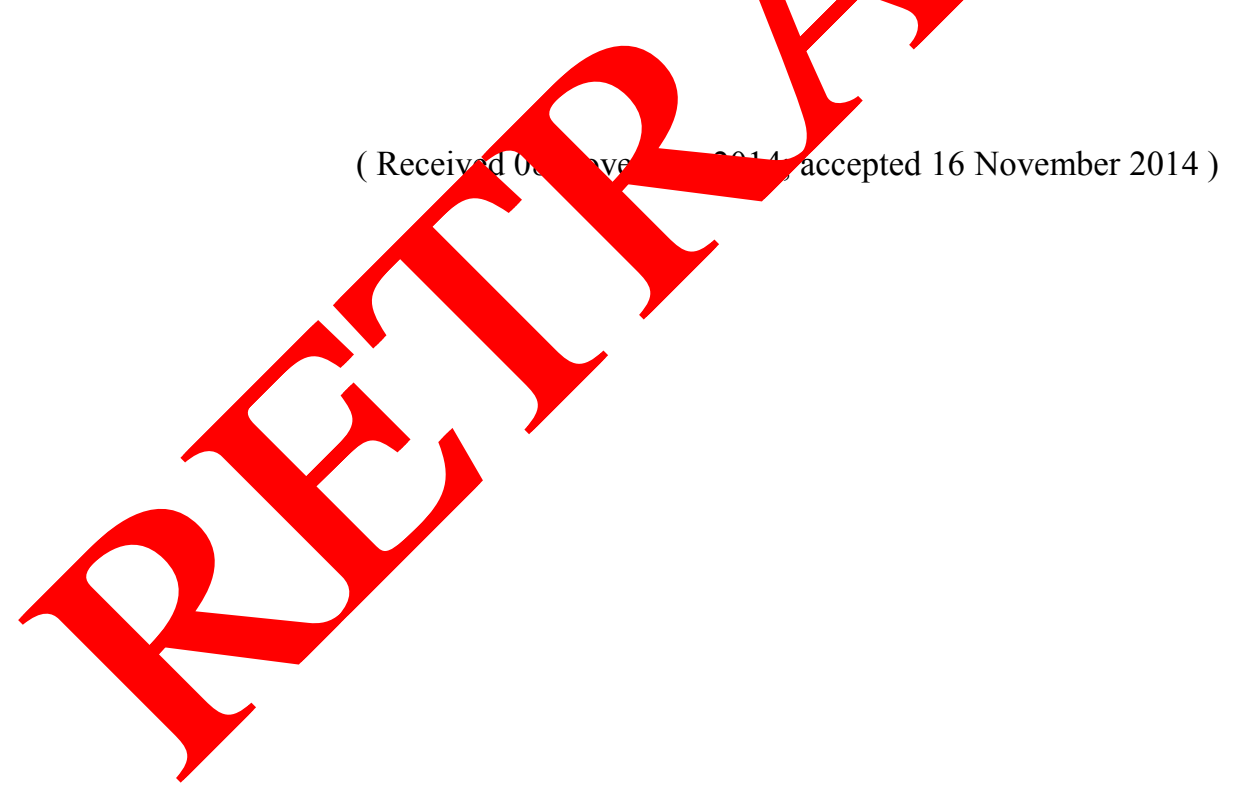

